\title{
РОЛЬ БУГАЇВ-ПЛІДНИКІВ, ОЦІНЕНИХ ЗА ТИПОМ ДОЧОК, У ФОРМУВАННІ СЕЛЕКЦІЙНОГО СТАДА ЗА ЕКСТЕР'ЄРОМ ТА МОЛОЧНОЮ ПРОДУКТИВНІСТЮ
}

\author{
Хмельничий Леонтій Михайлович \\ доктор сільськогосподарських наук, професор \\ Сумський національний аграрний університет \\ ORCID: 0000-0001-5175-1291 \\ E-mail: khmelnychy@ukr.net \\ Карпенко Богдан Миколайович \\ аспірант, спеціальність 204-ТВППТ \\ Сумський національний аграрний університет \\ ORCID: 0000-0002-9942-5863 \\ E-mail: karpenkobogdan95@gmail.com
}

За використання методики лінійної класифрікації оцінено бугаїв-плідників за типом їхніх дочок у стаді підприємства компанії "Укрлендфрармінг" ПП "Буринське" Підліснівського відділення Сумського району з розведення української чорнорябої молочної породи. Дифреренціація плідників за показники оцінки дочок за 100 бальною шкалою засвідчила істотну мінливість, яка залежить від їхнього походження. Кращими за рівнем оцінки виявилися дочки, отримані від голштинських плідників у порівнянні з ровеснииями, батьками яких є бугаї створеної вітчизняної української чорно-рябої молочної породи. Загалом, за загальноприйнятою міжнародною шкалою, показники оцінки усіх оцінюваних груп дочок бугаїв-плідників, незалежно від породної належності, відповідають класу «добре з плюсом» (80-84 бали). Дочки бугаїв-плідників голштинської породи, які характеризувались кращим розвитком групових ознак молочного типу (82,9-84,3 балу), тулуба (83,2-84,6 балу), кінцівок (82,8-83,5 балу), вимені (83,7-84,5 балу) та фінальною оцінкою за екстер'єрний тип (83,7-84,2 балу), аналогічно відзначались і вищими показниками за надоєм молока за першу (6782-7244 ке) та повновікову (8645-8931 ке) лактації. Встановлено кореляційну залежність величини надою за лактацію від групових ознак екстер'єру дочок оцінених за типом бугаїв-плідників, які характеризують вираженість молочного типу ( $r=0,215-0,478)$, розвиток тулуба $(r=0,286-0,484)$ та кінцівок ( $r=0,122-0,422)$, морфоологічні якості вимені $(r=0,264-0,461)$ та від фінальної оиінки типу $(r=0,231-0,468)$ з достовірністю $P<0,05-0,001$. Результати оцінки дочок бугаїв-плідників стада за описовими статями екстер'єру показали істотну мінливість оиінюваних ознак, яка варіює у межах 3,2-7,5 балу з мінливістю. коефіцієнтів варіації у межах 11,2-33,8\%, яка свідчать про необхідність їхнього поліпшення.

Ключові слова: українська чорно-ряба молочна порода, бугаї-плідники, лінійна оцінка типу, екстер'єр, кореляція.

DOI: https://doi.org/10.32845/bsnau.lvst.2021.3.4

Ефективне удосконалення корів молочної худоби за ознаками молочної продуктивності великою мірою ірунтується на об'єктивній оцінці, ретельному доборі та інтенсивному використанні бугаїв-плідників з відмінною племінною цінністю як за якісними показниками молока, так і за екстер'єрним типом. Раціональний підбір бугая-плідника задля відтворення стада $є$ досить важливим та відповідальним заходом, оскільки неодноразово доведено, що у галузі молочного скотарства вплив спадковості плідників у генетичне поліпшення стад та порід надзвичайно важливий компонент, особливо на сучасному етапі великомасштабної селекції [1, $14,16,25]$. Іншого варіанту не існує задля того, щоб узнати міру успадкування будь якої господарськи корисної ознаки, що обмежена статтю, яка характеризує самок і тільки їм притаманна, має бути оцінена у самців. Через це, визначення племінної цінності бугаїв-плідників за будовою тіла та вимені їхнього дочірнього потомства, поряд із показниками молочної продуктивності, займає провідне місце у селекційному процесі удосконалення молочних та комбінованих порід в усьому світі.

Найбільш ефективний та самий поширений у світовій практиці спосіб оцінки корів молочної худоби за екстер'єром - метод лінійної класифікації типу (Linear Type Classification), який уже тривалий період часу використовують і в Україні $[15,18]$. Остання редакція Закону України "Про племінну Вісник Сумського національного аграрного університету

справу у тваринництві" зобов'язує використовувати лінійну класифікацію у системі бонітування як складовий елемент у комплексній оцінці племінної цінності тварин [4].

Завдяки дослідженням з лінійної оцінки корів науковцями України встановлено закономірності формування будови тіла тварин створених українських червоної [12, 13], бурої [23, 27], червоно-рябої [19, 21] та чорно-рябої [6, 10, 24] молочних порід з визначенням у них мінливості та селекційно-генетичних параметрів ознак екстер'єру з оцінкою бугаїв-плідників за типом їхніх дочок та виявленням поліпшувачів типу $[6,13,15,18,19,22]$

3 огляду на важливість проблемного і непростого питання, яке виникає у процесі підбору до стада чергового бугая-плідника, варто об'єктивно уміти оцінювати селекційну ситуацію у стаді в аспекті формування екстер'єрного типу поголів'я взагалі та у межах використаних бугаїв-плідників зокрема через те, що лише завдяки їм успадковується як бажаний розвиток статей будови тіла, так i, на жаль, їхні недоліки $[7,8,17]$. Тому, у даному контексті вмотивованість та актуальність мети даного дослідження не викликає сумніву. До цього спонукає також популяційно-генетичний аспект, оскільки доведено існування додатного зв'язку між екстер'єрними ознаками корів та їхньою молочною продуктивністю який було встановлено у численних наукових експериментах, про що повідомляється як вітчизняними дослідни- 
ками, так і зарубіжними [2, 3, 5, 18, 19, 25, 28, 29].

Отже, впровадження у практику селекції молочного скотарства методу лінійної класиффікації, як обов'язкового елементу комплексної оцінки племінної цінності молочної худоби, потребує ретельного проведення оцінки бугаївплідників за екстер'єром їхніх дочок у конкретних умовах господарства задля виявлення серед них достовірних поліпшувачів типу та встановлення параметрів співвідносної мінливості між лінійними ознаками та величиною надою, що дозволить ефрективно використати їх для прискорення селекції стада як за екстер'єром, так і за продуктивністю.

Матеріали та методи досліджень. Експерименти проведено у стаді підприємства компанії "Укрлендфрармінг" ПП "Буринське" Підліснівського відділення Сумського району з розведення української чорно-рябої молочної породи. Для оцінки екстер'єру корів використовували методику лінійної класифікації молочних і молочно-м'ясних порід за типом [20] згідно попередніх [9] та останніх [26] рекомендацій ICAR у віці 2-4 місяців після отелення. Оцінювалися коровипервістки за двома системами: 9-бальною, з лінійним описом 18 статей екстер'єру і 100-бальною, з урахуванням чотирьох комплексів лінійних ознак з відповідним ваговим коефіцієнтом у сумі фінальної оцінки, які характеризують: вираженість молочного типу (15\%), розвиток тулуба (20\%), стан кінцівок (25\%) і морфологічні якості вимені (40\%). До описових ознак відносяться: висота (Вис.), ширина грудей (ШГ), глибина тулуба (ГТ), кутастість (Кутас.), положення заду (ПЗ), ширина заду (ШЗ), кут тазових кінцівок (КТК), постава тазових кінцівок (ПТК), переднє прикріплення вимені (ППВ), заднє прикріплення вимені (ЗПВ), центральна зв'язка (ЦЗ), глибина вимені (ГВ), розміщення передніх дійок (РПД), розміщення задніх дійок (РЗД), довжина дійок (ДД), переміщення (Хода) та вгодованість (Вгод). Матеріали досліджень опрацьовували методами біометричної статистики на ПК за формулами, наведеними Е.К. Меркурьевой [11].

Результати дослідження. Проведені науковогосподарські дослідження 3 лінійної класифікації корівпервісток піддослідного стада переконливо свідчать, що використання даної методики дозволяє на достатньо вірогідному рівні диференціювати бугаїв-плідників за екстер'єрними показниками будови тіла та вимені їхніх дочок, табл. 1.

Показники оцінки дочок бугаї-плідників даного стада за 100 бальною шкалою загалом відрізняється істотною мінливістю, яка залежить від їхнього походження і племінної цінності. Досить помітно виділяються за рівнем оцінки дочки, отримані від плідників голштинської породи у порівнянні з ровесницями, батьками яких $є$ бугаї створеної вітчизняної української чорно-рябої молочної породи.

Про вищі результати лінійної класифікації дочок голштинських бугаїв-плідників оцінюваного стада свідчать відповідні показники фінальної оцінки, які спостерігаються у потомства Г.Трістана 3021652032 (84,0 бали, лінія С.Т. Рокіта ), К.Реджімена 128891296 (83,8 балу, лінія Старбака), Манго 5300018703 (84,0 бали, лінія Валіанта), Ф.Л. Макдадді 138438344 (84,2 балу, лінія Маршала) та Дж. Руебен 137936344 (83,7 балу, лінія Старбака).

У дочок перерахованих вище бугаїв-плідників голштинської породи добре виражений молочний тип (82,9-84,3 балу). Вони перевищують оцінки за комплекс групових ознак дочок бугаїв української чорно-рябої молочної породи на 1,6-4,1 балу за високої та достовірної різниці за критерієм Стьюдента при $\mathrm{P}<0,001$.

Розвиток тулуба порівняно добре розвинений у потомства усіх оцінюваних бугаїв-плідників незалежно від породи і становить 3 мінливістю 82,8-84,6 балу, хоча різниця у 1,8 балу між крайніми варіантами достовірна на користь голштинських плідників $(\mathrm{P}<0,001)$.

Мінливість за оцінку ознак, які характеризують стан розвитку кінцівок на момент їхньої оцінки, не досить значна, за виключенням дочок бугая української чорно-рябої молочної породи Босфрора 5284 (79,4 балу). У решти дочок плідників оцінка становить у межах 81,7-83,5 балу з достовірною різницею 1,8 балу між крайніми варіантами.

Що стосується найважливішого комплексу - морфологічних ознак вимені, то за їхньою оцінкою кращими є дочірні представниці, отримані від голштинських плідників 3 оцінкою у межах від 80,6 (дочки К.Ф.П. Долса, ліня П.Ф.А.Чіфа) до 84,5 балу (дочки Ф.Л. Макдадді). У дочірнього потомства бугаїв української чорно-рябої молочної породи оцінка за ознаками вимені нижча з меншою мінливістю 80,2-80,8 балу.

Проте найважливіша оцінка, яка характеризує тип оціненого потомства бугаїв-плідників, це сумарна фінальна оцінка, що випливає із результатів оцінки чотирьох групових ознак. Загалом, за загальноприйнятою міжнародною шкалою, показники оцінки усіх оцінюваних груп дочок бугаївплідників, незалежно від породної належності, відповідають класу «добре з плюсом» (80-84 бали).

Результати оцінки дочірнього потомства бугаївплідників піддослідного господарства за описовими лінійними ознаками екстер'єрного типу свідчать про істотну мінливість оцінюваних ознак, яка варіює у межах від 3,2 балу за ознаку розміщення передніх дійок у дочок бугая Грізного 1907, до 7,8 балу за ознаку переднього прикріплення вимені у дочок бугая-плідника Г.Трістана 3021652032, табл. 2.

Вирізнити із усіх оцінюваних бугаїв-плідників беззаперечного лідера досить складно через вказану велику мінливість оцінок, проте кращими за більшою половиною описових статей, можна відмітити голштинських плідників взагалі та зокрема Г.Трістана. Його дочки відрізнялися вищими оцінками за розвиток ознак висоти (6,2 балу), кутастості (7,2 балу), ширини заду (6,8 балу), прикріплення передніх (7,8 балу) та задніх (6,9 балу) часток вимені, центральної зв'язки (6,8 балу), глибини вимені (6,7 балу), довжини дійок (4,8 балу) та переміщення (6,9 балу).

Із досліджень параметрів популяційної генетики нам добре відомо, що ефективність селекції будь-яких видів сільськогосподарських тварин залежить від ступеня мінливості тієї чи іншої селекціонованої кількісної ознаки. Якщо ознака найбільш мінлива за своєю природою, її значно простіше та швидше можна удосконалити й, навпаки, чим менш мінливіша ознака, тим гірше ії поліпшити [18]. Характер мінливості провідних господарськи корисних ознак визначається двома групами чинників - спадковістю та умовами зовнішнього середовища. 
Таблиця 1

Характеристика бугаїв-плідників голштинської та української чорно-рябої молочної порід оцінених за 100-бальною системою лінійної класифікації

\begin{tabular}{|c|c|c|c|c|c|c|c|c|c|c|c|}
\hline \multirow{3}{*}{$\begin{array}{c}\text { Кличка та ідентифікаційний } \\
\text { № бугая-плідника } \\
\text { (порода) }\end{array}$} & \multirow{3}{*}{$\mathrm{n}$} & \multicolumn{8}{|c|}{ Група лінійних ознак екстер'єру, які характеризують: } & \multirow{2}{*}{\multicolumn{2}{|c|}{$\begin{array}{c}\text { Фінальна } \\
\text { оцінка }\end{array}$}} \\
\hline & & \multicolumn{2}{|c|}{ молочний тип } & \multicolumn{2}{|c|}{ тулуб } & \multicolumn{2}{|c|}{ кінцівки } & \multicolumn{2}{|c|}{ вим'я } & & \\
\hline & & $x \pm$ S.E. & $\mathrm{Cv}, \%$ & $x \pm S . E$. & $\mathrm{Cv}, \%$ & $\mathrm{x} \pm$ S.E. & $\mathrm{Cv}, \%$ & $x \pm$ S.E. & $\mathrm{Cv}, \%$ & $x \pm$ S.E. & $\mathrm{Cv}, \%$ \\
\hline Босcрор 5284 (УЧР) & 35 & $81,3 \pm 0,33$ & 2,44 & $82,8 \pm 0,52$ & 3,77 & $79,4 \pm 0,42$ & 4,25 & $80,8 \pm 0,32$ & 3,32 & $81,0 \pm 0,28$ & 1,31 \\
\hline Г.Трістан 3021652032 (Г) & 51 & $83,5 \pm 0,25$ & 2,36 & $83,5 \pm 0,33$ & 2,51 & $82,8 \pm 0,23$ & 1,87 & $83,7 \pm 0,25$ & 2,24 & $84,0 \pm 0,20$ & 1,66 \\
\hline Вальс 8511 (УЧР) & 41 & $80,2 \pm 0,38$ & 3,18 & $82,9 \pm 0,23$ & 2,26 & $82,5 \pm 0,38$ & 2,41 & $80,3 \pm 0,38$ & 2,59 & $80,4 \pm 0,28$ & 1,81 \\
\hline К.Реджімен 128891296 (Г) & 45 & $83,6 \pm 0,24$ & 1,98 & $83,6 \pm 0,31$ & 2,33 & $82,8 \pm 0,34$ & 2,26 & $83,6 \pm 0,25$ & 1,78 & $83,8 \pm 0,17$ & 1,71 \\
\hline Грізний 1907 (УЧР) & 35 & $81,2 \pm 0,23$ & 2,22 & $82,2 \pm 0,23$ & 2,18 & $81,7 \pm 0,32$ & 2,38 & $80,2 \pm 0,41$ & 2,44 & $80,5 \pm 0,21$ & 1,83 \\
\hline Манго $5300018703(Г)$ & 50 & $82,9 \pm 0,24$ & 2,24 & $83,2 \pm 0,31$ & 2,31 & $82,8 \pm 0,21$ & 2,46 & $83,8 \pm 0,21$ & 2,42 & $84,0 \pm 0,17$ & 1,61 \\
\hline Мирний 5156 (УЧР) & 55 & $81,2 \pm 0,21$ & 2,14 & $82,7 \pm 0,24$ & 1,82 & $82,1 \pm 0,24$ & 3,24 & $80,5 \pm 0,19$ & 1,99 & $80,7 \pm 0,14$ & 1,43 \\
\hline Ф.Л. Макдадді 138438344 (Г) & 36 & $84,3 \pm 0,31$ & 2,48 & $84,6 \pm 0,33$ & 2,02 & $83,5 \pm 0,31$ & 2,23 & $84,5 \pm 0,38$ & 2,41 & $84,2 \pm 0,33$ & 1,55 \\
\hline К.Ф.П. Долс 139719547 (Г) & 22 & $80,6 \pm 0,38$ & 4,11 & $82,8 \pm 0,32$ & 3,74 & $81,7 \pm 0,37$ & 3,81 & $80,6 \pm 0,39$ & 3,04 & $81,3 \pm 0,35$ & 1,64 \\
\hline Г.Х.Б. Трей 66155210 (Г) & 29 & $82,8 \pm 0,34$ & 3,56 & $83,3 \pm 0,35$ & 3,25 & $82,5 \pm 0,29$ & 3,16 & $82,2 \pm 0,34$ & 2,87 & $82,6 \pm 0,36$ & 1,39 \\
\hline З.П. Темпо 53774726 (Г) & 27 & $80,8 \pm 0,28$ & 3,87 & $82,3 \pm 0,23$ & 3,14 & $82,8 \pm 0,26$ & 2,86 & $80,8 \pm 0,27$ & 2,69 & $81,6 \pm 0,28$ & 1,57 \\
\hline Дж. Руебен 137936344 (Г) & 33 & $83,5 \pm 0,25$ & 2,36 & $84,4 \pm 0,25$ & 2,82 & $83,4 \pm 0,26$ & 2,79 & $83,7 \pm 0,26$ & 2,58 & $83,7 \pm 0,24$ & 1,44 \\
\hline
\end{tabular}

Оцінка бугаїв-плідників за описовими ознаками екстер'єру 9-ти бальної шкали ( $\mathrm{x} \pm \mathrm{S} . \mathrm{E}$.)

Таблиця 2

\begin{tabular}{|c|c|c|c|c|c|c|c|c|c|c|c|c|}
\hline Ознака & Босфор & Трістан & Вальс & Реджімен & Грізний & Манго & Мирний & Макдадді & Долс & Трей & Темпо & Руебен \\
\hline Вис. & $4,2 \pm 0,16$ & $6,2 \pm 0,28$ & $5,9 \pm 0,41$ & $5,8 \pm 0,19$ & $4,9 \pm 0,26$ & $5,5 \pm 0,22$ & $4,2 \pm 0,18$ & $7,7 \pm 0,15$ & $5,9 \pm 0,21$ & $6,2 \pm 0,23$ & $5,7 \pm 0,23$ & $6,4 \pm 0,21$ \\
\hline ШГ & $\pm 0,19$ & $6,2 \pm 0,22$ & $8 \pm 0,25$ & $6,6 \pm 0$ & $5,8 \pm 0,19$ & $2 \pm 0,31$ & $5,9 \pm 0,14$ & $2 \pm 0,16$ & $6,8 \pm 0,24$ & $6,5 \pm 0,22$ & $7 \pm 0,22$ & $0 \pm 0,17$ \\
\hline ГТ & $5,8 \pm 0,15$ & $6,9 \pm 0,24$ & $6,9 \pm 0,26$ & $7,2 \pm 0,26$ & $6,0 \pm 0,15$ & $6,1 \pm 0,23$ & $6,9 \pm 0,15$ & $7,5 \pm 0,17$ & $6,5 \pm 0,21$ & $6,8 \pm 0,21$ & $5,8 \pm 0,19$ & $7,2 \pm 0,19$ \\
\hline Кутас. & $7,3 \pm 0,20$ & $7,2 \pm 0,16$ & $6,1 \pm 0,18$ & $6,9 \pm 0,26$ & $5,7 \pm 0,21$ & $6,2 \pm 0,20$ & $6,3 \pm 0,19$ & $7,3 \pm 0,20$ & $5,5 \pm 0,18$ & $6,5 \pm 0,19$ & $5,7 \pm 0,22$ & $6,9 \pm 0,23$ \\
\hline$\Pi 3$ & $5,0 \pm 0,19$ & $5,1 \pm 0,14$ & $5,8 \pm 0,21$ & $5,2 \pm 0,20$ & $5,5 \pm 0,14$ & $4,9 \pm 0,19$ & $5,5 \pm 0,13$ & $5,2 \pm 0,15$ & $6,1 \pm 0,19$ & $4,9 \pm 0,15$ & $5,8 \pm 0,21$ & $5,3 \pm 0,18$ \\
\hline 13 & $3 \pm 0,21$ & $6,8 \pm 0$ & $5,5 \pm 0,23$ & $6,9 \pm$ & $5,2 \pm 0$ & $6,7 \pm 0,20$ & $5,6 \pm$ &, 20 & $5,3 \pm$ & $6,5 \pm 0,21$ & $5,2 \pm 0,24$ & $6,6 \pm 0,16$ \\
\hline KTK & 18 & $4,9 \pm 0$ & $6,5=$ & $4,9 \pm$ & 5,5 & $4,2 \pm 0,18$ & $5,4 \pm$ & $5,3=$ & $4,5 \pm$ & $5,2 \pm 0,17$ & $4,2 \pm 0,18$ & $5,1 \pm 0,17$ \\
\hline ПТК & $6,7 \pm 0,22$ & $7,5 \pm 0,15$ & $6,7 \pm 0,15$ & $7,2 \pm 0,21$ & $6,9 \pm 0,15$ & $6,1 \pm 0,17$ & $6,2 \pm$ & $7,7 \pm 0,22$ & $5,5 \pm 0,19$ & $7,1 \pm 0,18$ & $5,4 \pm 0,22$ & $6,4 \pm 0,15$ \\
\hline $\mathrm{KP}$ & $5,8 \pm 0,24$ & $6,9 \pm 0,24$ & $5,1 \pm 0,19$ & $6,7 \pm 0,18$ & $5,5 \pm 0,28$ & $4,7 \pm 0,29$ & $5,1 \pm 0,19$ & $6,8 \pm 0,24$ & $3,4 \pm 0,28$ & $6,1 \pm 0,16$ & $4,4 \pm 0,19$ & $6,2 \pm 0,22$ \\
\hline$\Pi \Pi \mathrm{B}$ & $7,3 \pm 0,20$ & $7,8 \pm 0,22$ & $5,2 \pm 0,24$ & $6,9 \pm 0,20$ & $5,1 \pm 0,19$ & $5,2 \pm 0,23$ & $5,0 \pm 0,17$ & $7,3 \pm 0,25$ & $5,8 \pm 0,23$ & $6,5 \pm 0,17$ & $5,3 \pm 0,22$ & $6,8 \pm 0,24$ \\
\hline $3 П \mathrm{~B}$ & $6,3 \pm 0,24$ & $6,9 \pm 0,13$ & $5,6 \pm 0,15$ & $7,0 \pm$ & $5,4 \pm 0,27$ & $5,2 \pm 0,21$ & $5,2 \pm 0,18$ & $6,8 \pm$ & $5,4 \pm 0,19$ & $6,6 \pm 0,18$ & $5,5 \pm 0,21$ & $6,4 \pm 0,26$ \\
\hline 43 & $6,4 \pm 0,14$ & $6,8 \pm 0,14$ & $5,2 \pm 0,22$ & $6,1 \pm 0$ & $4,9 \pm 0,21$ & $5,2 \pm 0,23$ & $4,2 \pm 0$ & $7,1 \pm$ & $5,2 \pm 0,27$ & $6,5 \pm 0,23$ & $5,1 \pm 0,27$ & $6,8 \pm 0,32$ \\
\hline$\Gamma \mathrm{B}$ & $6,7 \pm 0,21$ & $6,3 \pm 0,27$ & $4,1 \pm 0,31$ & $6,8 \pm 0,25$ & $4,7 \pm 0,20$ & $4,2 \pm 0,21$ & $5,1 \pm$ & $7,2 \pm 0,22$ & $5,1 \pm 0,26$ & $6,1 \pm 0,21$ & $5,2 \pm 0,24$ & $6,7 \pm 0,27$ \\
\hline РПД & $4,7 \pm 0,15$ & $4,8 \pm 0,16$ & $5,4 \pm 0,18$ & $3,8 \pm 0,27$ & $3,2 \pm 0,18$ & $4,1 \pm 0,25$ & $4,3 \pm 0,17$ & $4,4 \pm 0,19$ & $4,6 \pm 0,19$ & $5,4 \pm 0,16$ & $4,3 \pm 0,23$ & $4,8 \pm 0,19$ \\
\hline РЗД & $4,8 \pm 0,17$ & $4,9 \pm 0,19$ & $5,2 \pm 0,27$ & $5,7 \pm 0,28$ & $5,2 \pm 0,14$ & $4,9 \pm 0,17$ & $4,9 \pm 0,18$ & $4,9 \pm$ & $4,8 \pm 0,17$ & $5,6 \pm 0,17$ & $4,2 \pm 0,21$ & $5,0 \pm 0,17$ \\
\hline ДД & $5,0 \pm 0,15$ & $4,8 \pm 0,14$ & $4,8 \pm 0,13$ & $5,0 \pm 0,12$ & $5,8 \pm 0,15$ & $5,8 \pm 0,13$ & $5,7 \pm 0,15$ & $5,1 \pm$ & $5,7 \pm 0,18$ & $5,2 \pm 0,14$ & $5,4 \pm 0,16$ & $5,1 \pm 0,17$ \\
\hline Хода & $7,4 \pm 0,12$ & $6,9 \pm 0,15$ & $6,8 \pm 0,24$ & $6,6 \pm 0,15$ & $6,4 \pm 0,24$ & $6,2 \pm 0,16$ & $7,1 \pm 0,26$ & $6,8 \pm 0,18$ & $6,2 \pm 0,17$ & $7,5 \pm 0,21$ & $5,4 \pm 0,18$ & $6,4 \pm 0,21$ \\
\hline Вгод. & $5,0 \pm 0,17$ & $6,4 \pm 0,23$ & $7,7 \pm 0,27$ & $5,6 \pm 0,23$ & $7,7 \pm 0,25$ & $7,2 \pm 0,24$ & $6,9 \pm 0,17$ & $5,5 \pm 0,23$ & $6,8 \pm 0,21$ & $6,5 \pm 0,22$ & $6,8 \pm 0,21$ & $6,2 \pm 0,22$ \\
\hline
\end{tabular}

Генетично обумовлена мінливість постачає селекціонерам науковцям та практикам безліч різноманітних форм, що дає можливість проводити відповідний добір та підбір згідно з вибраним напрямом селекційно-племінної роботи. Тобто селекційний прогрес забезпечується закріпленням у подальших поколіннях лише генетичної, а не модифікованої мінливості [14]. Разом з тим існує зворотній бік цього процесу, велика мінливість свідчить про недостатню консолідованість тварин за тією чи іншою ознакою.

Порівнюючи коефіцієнти мінливості групових ознак 3 описовими відмічаємо, що не залежно від походження за батьком у межах кожної оцінюваної описової статі екстер'єру, виявлено існування високої фенотипової мінливості, табл. 3.

Жодна із піддослідних груп дочірніх нащадків із 12 оцінених бугаїв-плідників не має абсолютної переваги над іншими за фенотиповою консолідацією усіх оцінюваних описових ознак. Найменші певною мірою коефіцієнти варіації у межах дочок оцінюваних бугаїв-плідників піддослідного стада спостерігаються за шириною грудей $(17,8-29,9 \%)$, глибиною тулуба $(10,7-22,4 \%)$, кутастістю $(13,3-25,3 \%)$, положенням заду $(15,4-23,5 \%)$, шириною заду $(14,7-28,3 \%)$, поставою задніх кінцівок (12,3-26,6\%), глибиною вимені
(15,7-29,7\%), розміщенням задніх дійок (14,8-28,6\%), довжиною дійок (11,2-19,5\%), переміщенням $(12,6-23,5)$ та вгодованістю (12,3-18,9\%), що свідчить про кращу загальну консолідованість стада за цими ознаками.

Навпаки, висока мінливість виявлена за ознаками висоти (12,4-36,9\%), кута тазових кінцівок (11,7-27,5\%), кута ратиць $(14,2-33,8 \%)$, переднього $(12,8-29,3 \%)$ та заднього прикріплення вимені (14,1-29,3\%), центральної зв'язки (12,4$44,1 \%)$, глибини вимені $(20,2-29,7 \%)$, розміщення передніх дійок (14,8-39,4\%), яка свідчать про необхідність їхнього поліпшення у значної частини піддослідного поголів'я стада з розведення української чорно-рябої молочної породи на сучасному етапі селекції за рахунок використання оцінених та виявлених бугаїв-поліпшувачів за екстер'єрним типом їхніх дочок.

Мотивація запровадження методики лінійної оцінки та добору молочної та комбінованої худоби за екстер'єрним типом, розпочинаючи з періоду її розробки та запровадження і до нинішнього часу, зумовлена насамперед існуванням зв'язку між розвитком окремих статей і пропорцій будови тіла з провідними показними молочної продуктивності корів, тривалістю та ефективністю їхнього довічного використання, відтворною здатністю та здоров'ям. Це було доведено вели- 
чезною кількістю наукових експериментів, які були спрямовані на виявлення подібних зв'язків.

Як реалізується доведений науковими дослідженнями взаємозв'язок між формою (екстер'єрним типом) і функцією (ознаками продуктивності), підкріплюється результатами наших експериментальних досліджень. Аналогічно кращими показниками молочної продуктивності, за даними першої та третьої лактацій, характеризуються дочірні потомки бугаїв-плідників, що мають вищі оцінки за результатами лінійної класифікації.
Дочки бугаїв-плідників голштинської породи Г.Трістана 3021652032, К.Реджімена 128891296, Манго 5300018703, Ф.Л.Макдадді 138438344 та Дж.Руебена 137936344, які характеризувались кращим розвитком групових ознак молочного типу (82,9-84,3 балу), тулуба (83,2-84,6 балу), кінцівок (82,8-83,5 балу), вимені (83,7-84,5 балу) та фінальною оцінкою за екстер'єрний тип (83,7-84,2 балу), аналогічно відзначались і вищими показниками за надоєм молока за першу (6782-7244 кг) та повновікову (8645-8931 кг) лактації, табл. 4.

Таблиця 3

Мінливість розвитку описових ознак екстер'єру дочок бугаїв-плідників (Cv, \%)

\begin{tabular}{|l|c|c|c|c|c|c|c|c|c|c|c|c|}
\hline \multicolumn{1}{|c|}{ Ознака } & Босфор & Г.Трістан & Вальс & К.Реджімен & Грізний & Манго & Мирний & Макдадді & Долс & Трей & Темпо & Руебен \\
\hline Вис. & 20,7 & 32,5 & 36,9 & 19,7 & 31,9 & 32,7 & 21,8 & 12,4 & 23,6 & 12,8 & 21,3 & 13,5 \\
\hline ШГ & 17,8 & 29,9 & 29,1 & 25,8 & 19,8 & 25,1 & 17,9 & 16,5 & 19,5 & 18,0 & 23,1 & 18,8 \\
\hline ГТ & 15,1 & 20,4 & 17,5 & 19,2 & 18,1 & 22,4 & 15,8 & 10,7 & 22,2 & 21,2 & 19,2 & 20,6 \\
\hline Кутас. & 14,3 & 13,3 & 15,6 & 17,4 & 22,2 & 20,8 & 19,7 & 19,4 & 25,3 & 15,9 & 16,7 & 19,4 \\
\hline ПЗ & 19,5 & 22,5 & 23,5 & 22,6 & 20,8 & 22,5 & 15,4 & 19,2 & 22,2 & 17,6 & 25,8 & 20,2 \\
\hline Ш3 & 27,3 & 27,3 & 25,8 & 23,7 & 15,6 & 27,3 & 22,9 & 15,5 & 24,8 & 13,6 & 28,3 & 14,7 \\
\hline КТК & 12,7 & 23,6 & 19,5 & 23,8 & 17,9 & 23,5 & 13,7 & 11,7 & 27,5 & 16,1 & 19,1 & 13,8 \\
\hline ПТК & 13,6 & 21,3 & 16,9 & 19,7 & 14,6 & 18,7 & 14,6 & 12,6 & 26,6 & 17,4 & 19,4 & 12,3 \\
\hline КР & 33,8 & 29,6 & 27,3 & 26,5 & 23,5 & 26,3 & 31,9 & 15,8 & 28,2 & 16,6 & 21,3 & 14,2 \\
\hline ППВ & 12,8 & 15,6 & 17,8 & 23,8 & 29,3 & 28,5 & 27,3 & 18,6 & 26,4 & 18,4 & 25,8 & 16,5 \\
\hline ЗПВ & 22,2 & 19,3 & 24,7 & 29,3 & 27,2 & 24,1 & 17,4 & 17,5 & 27,2 & 14,1 & 24,5 & 17,1 \\
\hline ЦЗ & 27,7 & 28,5 & 27,9 & 36,7 & 44,1 & 37,3 & 29,5 & 12,4 & 29,7 & 18,6 & 19,7 & 15,2 \\
\hline ГВ & 20,2 & 22,4 & 29,7 & 22,8 & 29,3 & 26,3 & 28,2 & 15,7 & 26,8 & 19,5 & 23,8 & 18,8 \\
\hline РПД & 23,8 & 27,8 & 28,5 & 39,4 & 28,6 & 31,4 & 29,8 & 14,8 & 22,1 & 18,3 & 24,9 & 16,2 \\
\hline РЗД & 15,4 & 23,5 & 25,2 & 24,3 & 22,4 & 17,9 & 28,6 & 15,5 & 21,3 & 17,2 & 22,6 & 14,8 \\
\hline ДД & 11,2 & 12,4 & 12,7 & 15,6 & 15,7 & 13,7 & 16,4 & 11,2 & 19,5 & 17,4 & 13,2 & 16,6 \\
\hline Хода & 12,6 & 13,4 & 23,5 & 18,4 & 19,6 & 18,9 & 22,3 & 13,6 & 17,8 & 15,6 & 20,5 & 15,4 \\
\hline Вгод. & 14,9 & 16,4 & 15,6 & 12,3 & 18,5 & 13,5 & 16,9 & 13,9 & 18,9 & 17,4 & 18,7 & 15,6 \\
\hline
\end{tabular}

Таблиця 4

Молочна продуктивність дочок бугаїв-плідників оцінених за методикою лінійної класифікації (x \pm S.E.)

\begin{tabular}{|l|c|c|c|c|c|c|c|c|}
\hline \multicolumn{1}{|c|}{$\begin{array}{c}\text { Кличка та іден. } \\
\text { № плідника }\end{array}$} & \multicolumn{3}{|c|}{ Перша лактація } & \multicolumn{4}{c|}{ Третя лактація } \\
\cline { 2 - 9 } & $\mathrm{n}$ & Надій, кг & $\%$ жиру & кг жиру & $\mathrm{n}$ & Надій, кг & $\%$ жиру & кг жиру \\
\hline Босфор 5284 & 35 & $5152 \pm 65,6$ & $3,84 \pm 0,022$ & $197,8 \pm 3,17$ & 32 & $5564 \pm 89,1$ & $3,79 \pm 0,021$ & $210,5 \pm 3,85$ \\
\hline $\begin{array}{l}\text { Г.Трістан } \\
3021652032\end{array}$ & 51 & $6822 \pm 58,6$ & $3,77 \pm 0,021$ & $257,2 \pm 5,74$ & 48 & $8774 \pm 93,3$ & $3,76 \pm 0,019$ & $321,1 \pm 7,26$ \\
\hline Вальс 8511 & 41 & $5436 \pm 93,4$ & $3,82 \pm 0,031$ & $207,7 \pm 3,64$ & 37 & $6185 \pm 98,4$ & $3,81 \pm 0,023$ & $235,6 \pm 4,93$ \\
\hline $\begin{array}{l}\text { К.Реджімен } \\
\text { 128891296 }\end{array}$ & 45 & $6938 \pm 89,5$ & $3,78 \pm 0,017$ & $262,3 \pm 3,31$ & 42 & $8844 \pm 96,5$ & $3,77 \pm 0,014$ & $333,4 \pm 4,04$ \\
\hline Грізний 1907 & 35 & $5271 \pm 93,2$ & $3,85 \pm 0,026$ & $202,9 \pm 4,26$ & 29 & $6365 \pm 91,7$ & $3,83 \pm 0,019$ & $247,8 \pm 3,75$ \\
\hline $\begin{array}{l}\text { Манго } \\
\text { 5300018703 }\end{array}$ & 50 & $6782 \pm 95,4$ & $3,75 \pm 0,013$ & $256,4 \pm 3,84$ & 48 & $8645 \pm 96,5$ & $3,73 \pm 0,017$ & $322,5 \pm 4,27$ \\
\hline Мирний 5156 & 55 & $5767 \pm 96,2$ & $3,81 \pm 0,019$ & $219,7 \pm 5,25$ & 51 & $6117 \pm 93,6$ & $3,78 \pm 0,019$ & $231,2 \pm 4,99$ \\
\hline $\begin{array}{l}\text { Ф.Л.Макдадді } \\
\text { 138438344 }\end{array}$ & 36 & $7244 \pm 92,5$ & $3,77 \pm 0,018$ & $273,1 \pm 3,88$ & 32 & $8931 \pm 98,3$ & $3,75 \pm 0,017$ & $334,9 \pm 5,02$ \\
\hline $\begin{array}{l}\text { К.Ф.П.Долс } \\
\text { 139719547 }\end{array}$ & 22 & $5925 \pm 104,7$ & $3,79 \pm 0,022$ & $224,6 \pm 5,25$ & 20 & $6457 \pm 113,4$ & $3,78 \pm 0,024$ & $244,1 \pm 5,11$ \\
\hline $\begin{array}{l}\text { Г.Х.Б.Трей } \\
66155210\end{array}$ & 29 & $6557 \pm 96,5$ & $3,79 \pm 0,020$ & $248,5 \pm 4,72$ & 25 & $7439 \pm 94,3$ & $3,76 \pm 0,026$ & $278,7 \pm 4,85$ \\
\hline $\begin{array}{l}\text { 3.П.Темпо } \\
\text { 53774726 }\end{array}$ & 27 & $6015 \pm 98,8$ & $3,80 \pm 0,024$ & $228,6 \pm 4,85$ & 26 & $7185 \pm 95,5$ & $3,74 \pm 0,029$ & $268,7 \pm 5,12$ \\
\hline $\begin{array}{l}\text { Дж.Руебен } \\
\text { 137936344 }\end{array}$ & 33 & $7011 \pm 83,2$ & $3,76 \pm 0,019$ & $263,6 \pm 3,74$ & 31 & $8598 \pm 89,1$ & $3,75 \pm 0,021$ & $322,4 \pm 4,03$ \\
\hline
\end{tabular}

Одним із головних чинників успішної селекції у стадах молочної худоби є ступінь співвідносної мінливості між провідними господарськи корисними ознаками. На сучасному етапі консолідації тварин молочних порід за екстер'єрним типом особливого значення набуває кореляційна мінливість лінійних ознак екстер'єру корів з молочною продуктивністю.

Одержаний нашими дослідженнями достовірний до- датний зв'язок більшості комплексів лінійних ознак з величиною надою дочок бугаїв-плідників піддослідного стада за першу лактацію переконливо свідчить про провідну роль спадковості бугаїв-плідників у поліпшенні екстер'єрного типу свого потомства, табл. 5.

Як свідчать коефіцієнти кореляцій, надій корівпервісток стада Підліснівської філії ПП «Буринське» зале- 
жить від статей, які характеризують вираженість молочного типу дочок оцінених за типом бугаїв-плідників ( $r=0,215$ $0,478)$, від розвитку ознак тулуба $(r=0,286-0,484)$ та кінцівок
( $r=0,122-0,422)$, морфологічних якостей вимені ( $r=0,264$ $0,461)$ та найбільш від загальної оцінки $(r=0,231-0,468) 3$ достовірністю при $\mathrm{P}<0,05-0,001$.

Таблиця 5

\section{Зв'язок оцінки груп лінійних ознак з величиною надою}

дочок бугаїв-плідників за першу лактацію (r)

\begin{tabular}{|c|c|c|c|c|c|c|}
\hline \multirow{2}{*}{$\begin{array}{c}\text { Кличка та ідентифікаційний } \\
\text { № бугая-плідника }\end{array}$} & \multirow{2}{*}{$\mathrm{n}$} & \multicolumn{4}{|c|}{ Група ознак екстер'єру, що характеризують: } & \multirow{2}{*}{ Фінальна оцінка } \\
\hline & & Молочний тип & тулуб & кінцівки & вим'я & \\
\hline Босфор 5284 & 35 & $0,325^{\star \star \star}$ & $0,361^{* \star *}$ & $0,422^{\star \star *}$ & $0,312^{\star \star} 9$ & $0,311^{\star \star *}$ \\
\hline Г.Трістан 3021652032 & 51 & $0,478^{\star * *}$ & $0,355^{\star * \star}$ & $0,122^{*}$ & $0,366^{\star *}$ & $0,455^{\star \star *}$ \\
\hline Вальс 8511 & 41 & $0,236^{*}$ & $0,296^{\star \star}$ & $0,185^{*}$ & $0,264^{\star *}$ & $0,231^{\star *}$ \\
\hline К.Реджімен 128891296 & 45 & $0,421^{* \star \star}$ & $0,484^{* \star \star}$ & $0,164^{*}$ & $0,376^{\star \star \star}$ & $0,404^{* * *}$ \\
\hline Грізний 1907 & 35 & $0,215^{*}$ & $0,362^{* * *}$ & $0,133^{*}$ & $0,347^{* * *}$ & $0,303^{* *}$ \\
\hline Манго 5300018703 & 50 & $0,351^{\star \star *}$ & $0,443^{\star * \star}$ & $0,211^{*}$ & $0,363^{\star *}$ & $0,468^{* * *}$ \\
\hline Мирний 5156 & 55 & $0,262^{*}$ & $0,334^{\star \star *}$ & $0,137^{*}$ & $0,323^{\star \star *}$ & $0,283^{* *}$ \\
\hline Ф.Л.Макдадді 138438344 & 36 & $0,424^{* \star *}$ & $0,377^{\star \star \star}$ & $0,187^{*}$ & $0,461^{* \star *}$ & $0,475^{\star \star *}$ \\
\hline К.Ф.П. Долс 139719547 & 22 & $0,282^{\star *}$ & $0,286^{\star \star}$ & $0,155^{*}$ & $0,312^{\star *}$ & $0,318^{\star *}$ \\
\hline Г.Х.Б. Трей 66155210 & 29 & $0,366^{* * *}$ & $0,353^{\star *}$ & $0,198^{*}$ & $0,417^{* \star *}$ & $0,424^{* * *}$ \\
\hline 3.П. Темпо 53774726 & 27 & $0,244^{* *}$ & $0,301^{* *}$ & $0,155^{*}$ & $0,335^{\star *}$ & $0,339^{\star \star}$ \\
\hline Дж. Руебен 137936344 & 33 & $0,368^{\star \star \star}$ & $0,386^{* \star \star}$ & $0,137^{*}$ & $0,324^{* \star \star}$ & $0,336^{\star \star \star}$ \\
\hline
\end{tabular}

Примітка:* достовірно при $P<0,05 ;{ }^{* *}$ - при $P<0,01 ;{ }^{* * *}$ - при $P<0,001$

Додатний зв'язок з надоєм спостерігався також за більшістю описових лінійних ознак екстер'єру у межах бугаївплідників з істотною мінливістю, табл. 6. Найперше, до них відносяться ті статі, які несуть функціональні навантаження, або розвиток яких зв'язаний з іншими статями, від яких залежить продуктивність тварин.

Таблиця 6

Зв'язок описових ознак екстер'єру дочок бугаїв-плідників з величиною надою за першу лактацію (r)

\begin{tabular}{|c|c|c|c|c|c|c|c|c|c|c|c|c|}
\hline Ознака & Боссрор & Трістан & Вальс & Реджімен & Грізний & Манго & Мирний & Макдадді & Долс & Трей & Темпо & Руебен \\
\hline$n$ & 35 & 51 & 41 & 45 & 35 & 50 & 55 & 36 & 22 & 29 & 27 & 33 \\
\hline Вис. & $0,213^{2}$ & $0,233^{1}$ & 0,174 & $0,237^{1}$ & $0,351^{3}$ & $0,212^{1}$ & $0,206^{1}$ & $0,303^{2}$ & 0,2141 & $0,266^{1}$ & 0,1241 & $0,244^{2}$ \\
\hline ШГ & 0,123 & 0,092 & 0,036 & 0,122 & 0,069 & 0,031 & 0,044 & 0,077 & 0,155 & 0,104 & 0,125 & 0,074 \\
\hline$\Gamma \mathrm{TT}$ & $0,431^{3}$ & $0,477^{3}$ & $0,297^{1}$ & $0,388^{3}$ & $0,241^{2}$ & $0,334^{3}$ & $0,484^{3}$ & $0,324^{3}$ & $0,282^{2}$ & $0,311^{2}$ & $0,226^{1}$ & $0,293^{2}$ \\
\hline Кутас. & $0,458^{3}$ & $0,494^{3}$ & $0,247^{2}$ & $0,492^{3}$ & $0,487^{3}$ & $0,324^{3}$ & $0,363^{3}$ & $0,395^{3}$ & $0,328^{2}$ & $0,362^{2}$ & $0,277^{1}$ & $0,345^{2}$ \\
\hline$\Pi 3$ & $0,158^{1}$ & 0,051 & 0,103 & $0,131^{1}$ & 0,035 & 0,084 & $-0,021$ & 0,131 & 0,118 & 0,114 & 0,091 & 0,122 \\
\hline Ш3 & $0,344^{3}$ & $0,421^{3}$ & $0,369^{3}$ & $0,322^{3}$ & $0,215^{2}$ & $0,233^{2}$ & $0,184^{1}$ & $0,287^{2}$ & $0,251^{2}$ & $0,272^{2}$ & $0,214^{1}$ & $0,242^{1}$ \\
\hline KTK & $-0,088$ & $-0,027$ & $-0,062$ & 0,011 & 0,023 & 0,087 & 0,036 & 0,112 & 0,081 & 0,081 & $-0,022$ & 0,092 \\
\hline ПТК & $0,225^{1}$ & $0,231^{1}$ & $0,212^{1}$ & $0,159^{1}$ & $0,214^{1}$ & $0,227^{2}$ & $0,304^{2}$ & $0,286^{2}$ & $0,232^{1}$ & $0,248^{1}$ & $0,217^{1}$ & $0,241^{1}$ \\
\hline $\mathrm{KP}$ & $0,221^{1}$ & 0,087 & $0,154^{1}$ & $-0,082$ & $-0,055$ & 0,078 & $-0,054$ & $0,196^{1}$ & 0,122 & $0,181^{1}$ & 0,063 & 0,118 \\
\hline$\Pi \Pi B$ & $0,381^{3}$ & $0,458^{3}$ & $0,255^{2}$ & $0,382^{3}$ & $0,233^{1}$ & $0,227^{1}$ & $0,234^{2}$ & $0,384^{3}$ & $0,282^{2}$ & $0,298^{2}$ & $0,244^{1}$ & $0,284^{2}$ \\
\hline $3 П \mathrm{~B}$ & $0,328^{3}$ & $0,355^{3}$ & $0,148^{1}$ & $0,153^{1}$ & $0,266^{1}$ & $0,333^{3}$ & $0,178^{1}$ & $0,292^{2}$ & $0,194^{1}$ & $0,264^{2}$ & $0,164^{1}$ & $0,268^{2}$ \\
\hline Ц3 & $0,347^{3}$ & $0,247^{1}$ & $0,231^{1}$ & $0,288^{2}$ & $0,195^{1}$ & $0,236^{2}$ & 0,106 & $0,312^{2}$ & $0,168^{1}$ & $0,277^{2}$ & $0,181^{1}$ & $0,145^{1}$ \\
\hline$\Gamma \mathrm{T}$ & $-0,118$ & 0,022 & $-0,019$ & $-0,013$ & 0,066 & $-0,014$ & $-0,031$ & 0,083 & 0,137 & 0,098 & $-0,027$ & $-0,093$ \\
\hline РПД & $-0,011$ & 0,018 & $-0,084$ & 0,066 & 0,024 & $-0,036$ & $-0,022$ & $-0,056$ & 0,052 & 0,088 & $-0,053$ & 0,102 \\
\hline РЗД & $-0,013$ & $-0,037$ & $-0,042$ & 0,049 & $-0,034$ & $-0,033$ & $-0,037$ & $-0,024$ & 0,047 & $-0,107$ & $-0,042$ & 0,039 \\
\hline ДД & 0,077 & $-0,018$ & 0,045 & $-0,033$ & 0,066 & $-0,064$ & 0,057 & 0,083 & 0,063 & $-0,018$ & 0,088 & $-0,056$ \\
\hline Хода & $-0,123$ & 0,028 & 0,045 & 0,039 & $-0,086$ & $-0,085$ & $-0,044$ & $0,187^{1}$ & 0,122 & $0,128^{1}$ & $0,136^{1}$ & $0,175^{1}$ \\
\hline Вгод. & $-0,321^{3}$ & $-0,325^{3}$ & $-0,317^{3}$ & $-0,337^{3}$ & $-0,269^{2}$ & $-0,213^{2}$ & $-0,236^{1}$ & $-0,322^{2}$ & $-0,248^{1}$ & $-0,265^{2}$ & $-0,118^{1}$ & $-0,228^{2}$ \\
\hline
\end{tabular}

Про позитивний вплив висоти тварини, яка є інтегрованим показником загального її розвитку, на кількість надоєного молока, свідчать додатні коефріцієнти кореляції між цими ознаками у потомства усіх бугаїв-плідників господарства, від недостовірного ( $r=0,174)$ - у дочок Вальса лінії Забавного до високодостовірного $(r=0,351 ; P<0,001)$ - у дочок бугая Грізного лінії Валіанта.

За ознакою ширини грудей відсутній достовірний зв'язок з величиною надою з мінливістю коефріцієнтів кореляції у межах 0,036-0,155.

Глибина тулуба, від розвитку якої залежить можливість корів спожити більшу кількість грубих кормів та отримувати відповідно вищу продуктивність, також істотним чином визначає рівень надою у дочок бугаїв-плідників підприємства з коефріцієнтами кореляцій від 0,226 $(\mathrm{P}<0,05)$ до
$0,484(P<0,001)$.

Істотну залежність надою корів від лінійної ознаки за кутастість, яка характеризує молочний тип тварин, обґрунтовують отримані достовірні коефіцієнти кореляцій між цією ознакою та надоєм за лактацію у дочок бугаїв, які варіюють 3 мінливістю від 0,247 ( $\mathrm{P}<0,01$; дочки Вальса) до 0,494 ( $\mathrm{P}<0,001 ;$ дочки Г.Трістана).

Наступна важлива лінійна ознака, за якою спостерігається додатна кореляція з величиною надою за лактацію це ширина заду. Коефріцієнти кореляції у цьому дослідженні, за названими ознаками, що співвідносяться, варіюють у межах 0,184-0,421 ( $\mathrm{P}<0,01-0,001)$.

Система лінійної класифікації приділяє величезну увагу оцінці ознак, які характеризують морфологічну будову вим'я, що мотивує до прискіпливого визначення рівня 
зв'язку між розвитком цих ознак з надоєм тварин за лактацію. Із включених до лінійної класифікації морфологічних статей вимені найбільш надійно корелюють 3 надоєм прикріплення передніх часток вим'я, хоча мінливість коефіцієнтів кореляції за оцінкою цього зв'язку коливається у досить широких межах, від 0,227 ( $\mathrm{P}<0,05$; дочки бугая Манго) до 0,458 (P<0,001; дочки бугая Г.Трістана).

Ознака заднього прикріплення вимені, яка оцінюється за висотою та міцністю прикріплення і виконує підтримуючу функцію, корелює з надоєм ще з вищою мінливістю від 0,148 ( $\mathrm{P}<0,05$; дочки Вальса) до 0,355 ( $\mathrm{P}<0,001$; дочки бугая Г.Трістана).

Центральна зв'язка, яка також виконує підтримуючу функцію вимені, запобігаючи з віком його обвисанню, відрізняється додатною спрямованістю кореляцій з надоєм за різного ступеня мінливості, від недостовірного $(r=0,106)$ до високої достовірності $(r=0,347 \mathrm{P}<0,001)$.

Від'ємна кореляція у більшості дочок оцінюваних бугаїв виявлена за ознаками глибини вимені $(r=0,118 \ldots 0,137)$, яке під вагою молока певним чином обвисає вниз, та розміщенням передніх $(r=-0,084 \ldots 0,102)$ і задніх дійок ( $r=-$ $0,107 \ldots 0,049)$, оскільки із зростанням надою вим'я наповнюється молоком збільшуючись в об'ємі, при цьому відстань між дійками також збільшується, проте оцінка при цьому знижується.
Достовірна з від'ємним значенням кореляція встановлена між вгодованістю та надоєм ( $r=-0,337 \ldots-0,118)$, оскільки високопродуктивні тварини спеціалізованих молочних порід не бувають достатньо вгодованими. За від'ємного енергетичного балансу вони "здоюються з тіла" у перший період лактації, який якраз співпадає з часом оцінки упродовж 2-4 місяців.

Висновки. 1. За результатами досліджень встановлена диференціація бугаїв-плідників за екстер'єрним типом їхніх дочок. Кращими за лінійною оцінкою виявилися дочки, отримані від плідників голштинської породи у порівнянні 3 ровесницями, батьками яких є бугаї української чорно-рябої молочної.

2. Результати оцінки дочок бугаїв-плідників стада за описовими статями екстер'єру показали істотну варіабельність оцінюваних ознак у межах 3,2-7,5 балу з мінливістю коефіцієнтів варіації у границях 11,2-33,8\%, яка свідчать про необхідність їхнього поліпшення у значної частини поголівя стада.

3. Отримані додатні показники кореляцій між надоєм корів-первісток та груповими і окремими описовими лінійними ознаками буде сприяти есективності селекції тварин у напрямку їхнього поліпшення як за екстер'єром, так і за молочною продуктивністю.

\section{Список використаної літератури:}

1. Басовський М. 3., Рудик І. А., Буркат В. П. Вирощування, оцінка і використання плідників. К.: Урожай, 1992.216 с.

2. Буркат В. П., Полупан Ю. П., Йовенко І. О. Лінійна оцінка корів за типом. К.: Аграрна наука, 2004. 88 с.

3. Ефимова Л. В., Кулакова Т. В., Иванова О. В., Иванов Е. А. Взаимосвязь между признаками линейной оценки экстерьера и молочной продуктивностью коров. Вестник НГАУ (Новосибирский государственный аграрный университет). 2017. (3):115-124.

4. Закон України "Про внесення змін до Закону України "Про племінне тваринництво". "Голос України". 25 січня 2000 p. № 13 (2260). С. $4-5.17$

5. Клопенко Н. І., Рудик І. А. Використання селекційно-генетичних параметрів у селекції стада молочної худоби. Технологія виробництва і переробки продукції тваринництва. Біла Церква. 2010. Вип. 3 (72). С. 180-182.

6. Когут М. І. Оцінка бугаїв-плідників за типом будови тіла їх дочок. Предгірне та гірське землеробство і тваринництво. 2014. № 56 (2). C. 144-149.

7. Контэ А. Ф., Ермилов А. Н., Сермягин А. А. Оценка динамики генетической изменчивости для показателей типа телосложения коров-первотелок голштинизированной черно-пестрой породы. Вестник КрасГАУ. 2020 . № 8 (161). С. 69-78.

8. Контэ А. Ф., Ермилов А. Н., Янчуков И. Н., Сермягин А. А. Параметры генетической взаимосвязи недостатков экстерьера с оценкой типа телосложения голштинизированных коров черно-пестрой породы. Генетика и разведение животных. 2018. №3. С. 32-38.

9. Ладика В. І., Хмельничий Л. М., Буркат В. П., Рубан С. Ю. Реєстрація ICAR. Довідник.Суми: Сумський національний аграрний університет, 2010. 457 с.

10. Ладика В. І., Хмельничий Л. М., Салогуб А. М. Сполучна мінливість статей екстер'єру корів з молочною продуктивністю. Збірник наукових праць Білоцерківського НАУ Технологія виробництва і переробки продукції тваринництва. Біла Церква. 2010. Вип. 3 (72). С. 9-11.

11. Меркурьева Е. К. Генетические основы селекции в скотоводстве. М.: Колос, 1977. 240 с.

12. Полупан Ю. П. Онтогенетичні та селекційні закономірності формування господарськи корисних ознак молочної худоби : дис. ... д-ра с.-г. наук : 06.02.01 / Ін-т розведення і генетики тварин НААН. Чубинське, 2013. 694 с.

13. Полупан Ю. П. Оцінка бугаїв за типом дочок. Вісник аграрної науки. 2000. № 5. С. 45-49.

14. Полупан Ю. П. Суб'єктивні акценти з деяких питань основ селекції та породоутворення. Розведення і генетика тварин. Міжвідомчий тематичний збірник. К.: Аграрна наука. 2007. Вип.41. С. 194-208.

15. Полупан Ю. П. Удосконалення методики бонітування корів молочних порід за екстер'єром. Методологія наукових досліджень з питань селекції, генетики та біотехнології у тваринництві. Матеріали науково-теоретичної конференції, присвяченої пам'яті академіка УААН Валерія Петровича Бурката (Чубинське, 25 лютого 2010 року). К. : Аграрна наука, 2010. С. 9598.

16. Прохоренко П., Сакса Е., Тулинова О. Влияние предков на повышение генетического потенциала коров. Молочное и мясное скотоводство. 2006. №7. С.11-12.

17. Фураева Н. С. Особенности экстерьера молочного скота ярославской породы. Вестник АПК Верхневолжья. 2014. 
№ 4 (28). C. 44-49.

18. Хмельничий Л. М. Оцінка екстер'єру тварин в системі селекції молочної худоби : монографрія. Суми: ВВП "Мрія-1" TOB, 2007. $260 \mathrm{c}$.

19. Хмельничий Л. М. Реалізація спадковості бугаїв-плідників у співвідносній мінливості лінійної оцінки з молочною продуктивністю корів у віковій динаміці лактацій. Розведення і генетика тварин. К.: Аграрна наука. 2009. Вип. 43. С. 329-339.

20. Хмельничий Л. М., Ладика В. І., Полупан Ю. П., Салогуб А. М. Методика лінійної класифікації корів молочних і молочно-м'ясних порід за типом. Суми: ВВП “Мрія-1" ТОВ, 2008. 28 с.

21. Хмельничий Л. М., Лобода В. П. Ступінь успадковуваності лінійних ознак екстер'єру корів-первісток української червоно-рябої молочної породи. Науковий вісник Луганського НАУ, серія: «Сільськогосподарські науки». Луганськ: Елтон-2. 2013. № 54. С. 147-149.

22. Хмельничий Л. М., Лобода В. П., Шевченко А. П. Фенотипова та сполучена мінливість лінійних ознак екстер'єру корів молочних порід Сумщини. Розведення і генетика тварин. Міжвідомчий тематичний науковий збірник. К.: 2015. Вип. 50. C.103-111.

23. Хмельничий Л. М., Салогуб А. М. Екстер'єрний тип та продуктивність корів-первісток бурої худоби. Проблеми зо0інженерії та ветеринарної медицини: 3б. наук. пр. Харківської зооветакад. Харків. 2009. Вип. 18. Ч. 1. С. 311-316.

24. Черняк Н., Гончарук О. Екстер’єр корів чорно-рябої молочної породи різних ліній. Тваринництво України. 2011. № 1-2 (21). C. $22-25$.

25. Atkins, G., Shannon, J., Muir, B. Using Conformational Anatomy to Identify Functionality and Economics of Dairy Cows. WCDS Advances in Dairy Technology. 2008. 20: 279-295.

26. ICAR Guidelines for Conformation Recording of Dairy Cattle, Beef Cattle and Dairy Goats, 1/76. Section - 5, Conforma ion Recording, version June, 2018. [Електронний ресурс]. - Режим доступу: https://www.icar.org/Guidelines/05-ConformationRecording.pdf

27. Ladyka V. I., Khmelnychyi L. M., Khmelnychyi S. L. Conformation types of brown cattle of Sumy region of Ukraine (Monograph). Lublin, 2019.133 p

28. Madrid S., Echeverri J. Association between conformation traits and productive performance in Holstein cows in the department of Antioquia, Colombia. Veterinaria y Zootecnía. 2014. 8 (1). P. 35-47.

29. Otwinowska-Mindur A., Ptak E., Jagusiak W. Genetic relationship between lactation persistency and conformation traits in Polish Holstein-Friesian cow population. Czech J. Anim. Sci. 2016. 61 (2). P. 75-81.

\section{References:}

1. Basovskyi, M.Z. Rudyk I.A. and Burkat V.P., 1992. Vyroshchuvannia, otsinka i vykorystannia plidnykiv [Growth, estimation and use of sires]. Kyiv: Urozhay.

2. Burkat V.P., Polupan, lu.P. and Yovenko I.V., 2004. Liniina otsinka koriv za typom [Linear estimation of cows by type]. Kyiv: Ahrarna nauka.

3. Efimova, L.V., Kulakova, T.V., Ivanova, O.V., and Ivanov, E.A., 2017. Vzaimosvjaz' mezhdu priznakami linejnoj ocenki jekster'era i molochnoj produktivnost'ju korov [The relationship between traits of linear assessment of the conformation and cows milk productivity]. Bulletin of Novosibirsk State Agrarian University, issue 3(44), 115-124.

4. Law of Ukraine on amendments to the Law of Ukraine "On Pedigree Livestock" 2000. Holos Ukrainy, 25 Jan, № 13 (2260), pp. 4-5.

5. Klopenko, N.I. and Rudyk, I.A., 2010. Vykorystannia selektsiino-henetychnykh parametriv u selektsii stada molochnoi khudoby [The use of selection and genetic parameters in the selection of dairy cattle]. Tekhnolohiia vyrobnytstva i pererobky produktsii tvarynnytstva. Bila Tserkva, issue 3(72), pp. 180-182.

6. Kohut, M.I., 2014. Otsinka buhaiv-plidnykiv za typom budovy tila yikh dochok. [Estimation of sires by body type of their daughters]. Predhirne ta hirske zemlerobstvo i tvarynnytstvo, no. 56(2), pp. 144-149

7. Konte, A.F., Ermilov, and A.N., Sermyagin, A.A., 2020. Otsenka dinamiki geneticheskoy izmenchivosti dlya pokazateley tipa teloslozheniya korov-pervotelok golshtinizirovannoy cherno-pestroy porody [Assessment of the dynamics of genetic variability for indicators of the first-calf cows body type of the Holsteinized Black-and-White breed]. Vestnik Krasnoyarskogo GAU, no. 8(161), pp. 69-78.

8. Konte, A.F., Ermilov, A.N., Yanchukov, I.N. and Sermyagin, A.A., 2018. Parametry geneticheskoy vzaimosvyazi nedostatkov ekster'era s otsenkoy tipa teloslozheniya golshtinizirovannykh korov cherno-pestroy porody [Parameters of genetic relationship of conformation shortcomings with body type assessment holsteinized cows of Black-and-White breed]. Genetika $i$ razvedenie zhivotnykh, no. 3, pp. 32-38.

9. Ladyka, V.I., Khmelnychyi, L.M., Burkat, V.P. and Ruban, S.Yu., 2010. Reyestratsiya ICAR. Dovidnyk [ICAR Registration: Reference book]. Sumy: Sumy National Agrarian University.

10. Ladyka, V.I., Khmelnychyi, L.M., and Salohub, A.M., 2010. Spoluchna minlyvist statei eksterieru koriv z molochnoiu produktyvnistiu [Connecting conformation variability of body parts cow's with milk productivity]. Zbirnyk naukovykh prats Bilotserkivskoho NAU Tekhnolohiia vyrobnytstva i pererobky produktsii tvarynnytstva. Bila Tserkva, issue 3(72), pp. 9-11.

11. Merkur'eva, E. K., 1977. Geneticheskie osnovy selektsii v skotovodstve [Genetic bases of selection in animal husbandry]. Moskva: Kolos.

12. Polupan, Yu. P., 2013. Ontogenetic and breeding regularities formation of economically useful traits of Dairy cattle. Doctor's thesis of Agricultural sciences. Institute of Animals breeding and Genetics NAAS, Chubynske.

Вісник Сумського національного аграрного університету 
13. Polupan, Yu. P., 2000. Otsinka buhaiv za typom dochok [Estimation of sires according to the type of daughters]. Visnyk ahrarnoi nauky, issue 5, pp. 45-49.

14. Polupan, Yu.P., 2007. Subiektyvni aktsenty z deiakykh pytan osnov selektsii ta porodoutvorennia [Subjective accents on some questions about genetic basis of selection and breed formation]. Rozvedennia i henetyka tvaryn, issue 41, pp. $194-208$.

15. Polupan, Yu.P. 2010. Udoskonalennia metodyky bonituvannia koriv molochnykh porid za eksterierom. Metodolohiia naukovykh doslidzhen z pytan selektsii, henetyky ta biotekhnolohii u tvarynnytstvi [Improved methods bonitation dairy cows on the conformation. Research methodology on breeding, genetics and biotechnology in animal husbandry]. Proceedings of the scientifictheoretical conference dedicated to the memory of UAAS academician Burkat V.P., (Chubynske, 25 liutoho 2010 roku). K. : Ahrarna nauka, pp. 95-98.

16. Prokhorenko, P., Saksa, E. and Tulinova, O., 2006. Vliyanie predkov na povyshenie geneticheskogo potentsiala korov [The impact of ancestors at improving the genetic potential of cows]. Molochnoe i myasnoe skotovodstvo, no. 7, pp. 11-12.

17. Furaeva, N.S., 2014. Osobennosti ekster'era molochnogo skota yaroslavskoy porody [Features of the conformation of dairy cattle of the Yaroslavl breed]. Vestnik APK Verkhnevolzh'ya, no. 4(28), pp. 44-49.

18. Khmelnychyi, L.M., 2007. Otsinka eksterieru tvaryn v systemi selektsii molochnoi khudoby: monohrafiia [Assessment of the cow's conformation in dairy cattle breeding system: monograph]. Sumy: Mriia-1.

19. Khmelnychyi, L.M., 2009. Realizatsiia spadkovosti buhaiv-plidnykiv u spivvidnosnii minlyvosti liniinoi otsinky z molochnoiu produktyvnistiu koriv u vikovii dynamitsi laktatsii [Realization of sires inheritance in relative variability of linear assessment with cow's milk productivity in lactations age dynamics]. Rozvedennia i henetyka tvaryn, no. 43, pp. 329-339.

20. Khmelnychyi, L.M., Ladyka, V.I., Polupan, Yu.P., and Salohub, A.M., 2008. Metodyka liniinoi klasyfikatsii koriv molochnykh i molochno-miasnykh porid za typom [Method of linear classification of dairy cows and dairy-meat breeds by type]. Sumy: Mriia-1.

21. Khmelnychyi, L.M., and Loboda, V.P., 2013. Stupin uspadkovuvanosti liniinykh oznak eksterieru koriv-pervistok ukrainskoi chervono-riaboi molochnoi porody [The degree of heritability linear conformation traits of cows firstborn Ukrainian Redand-White dairy breed]. Naukovyi visnyk Luhanskoho NAU, no. 54, pp. 147-149.

22. Khmelnychyi, L.M., Loboda, V.P., and Shevchenko, A.P., 2015. Fenotypova ta spoluchena minlyvist liniinykh oznak eksterieru koriv molochnykh porid Sumshchyny [Phenotypic and communicating variability of linear conformation traits of dairy cows in Sumy region]. Rozvedennia i henetyka tvaryn, issue 50, pp. 103-111.

23. Khmelnychyi, L.M. and Salohub, A.M., 2009. Eksteriernyi typ ta produktyvnist koriv-pervistok buroi khudoby [Conformation type and productivity of cows firstborn of Brown cattle]. Zbirnyk naukovykh prats Kharkivskoi zoovetakademii, issue 18(1), pp. 311-316.

24. Cherniak, N.H. and Honcharuk, O.P., 2011. Eksterier koriv chorno-riaboi molochnoi porody riznykh linii [The conformation Black-and-White cows dairy breed different lines]. Tvarynnytstvo Ukrainy, issue 1/2(21), pp. 22-25.

25. Atkins, G., Shannon, J., Muir, B. 2008. Using conformational anatomy to identify functionality and economics of dairy cows. WCDS Advances in Dairy Technology, 20: 279-295.

26. ICAR Guidelines for conformation recording of dairy cattle, beef cattle and dairy goats, 1/76. Section 5 , Conformation Recording, version June, 2018. [Електронний ресурc]. Режим доступу: https://www.icar.org/Guidelines/05-ConformationRecording. pdf

27. Ladyka, V.I., Khmelnychyi, L.M., and Khmelnychyi, S.L., 2019. Conformation types of Brown cattle in Sumy region of Ukraine (Monograph). Lublin.

28. Madrid, S., Echeverri, J., 2014. Association between conformation traits and productive performance in Holstein cows in the department of Antioquia, Colombia. Veterinaria y Zootecnía, 8(1), P. 35-47.

29. Otwinowska-Mindur, A., Ptak E., and Jagusiak, W., 2016. Genetic relationship between lactation persistency and conformation traits in Polish Holstein-Friesian cow population. Czech J. Anim. Sci., 61(2), P. 75-81.

Khmelnychyi Leontii Mykhailovych, Doctor of Agricultural Sciences, Professor

Karpenko Bogdan Mykolaiovych, Graduate student

Sumy National Agrarian University (Sumy, Ukraine)

The role of bull-sires evaluated by the type of their daughters in the formation of breeding herd for the conformation and milk productivity

By using the method of linear classification, breeding sires were evaluated by the type of their daughters in the herd of enterprise of the company "Ukrlandfarming" PE "Burynske" Pidlisnivskyi branch in Sumy region for breeding Ukrainian Black-and-White dairy breed. Differentiation of the offspring according to daughter's assessment by 100-score scale showed significant variability, which depended on their origin. The daughters obtained from Holstein sires were better in terms of estimation in comparison with their peers, whose parents were bull-sires of the created aboriginal Ukrainian Black-and-White dairy breed. In general, according to the generally accepted international scale, assessment indicators of all evaluated groups of sires daughters, regardless of breed, corresponded to the class "good with plus" (80-84 scores). Daughters of bull-sires of the Holstein breed, which were characterized by the best development of the dairy type group traits (82.9-84.3 scores), body (83.2-84.6 scores), limbs (82.8-83.5 scores), udder (83.7-84.5 scores) and the final score for the conformation type (83.7-84.2 scores), similarly differed by higher milk yield of the first $(6782-7244 \mathrm{~kg})$ and full-age (8645 - $8931 \mathrm{~kg})$ lactation. The correlation was established between the milk yield per lactation and the group of conformation traits of daughters assessed by the type of sires, thatch characterize the severity of dairy type ( $r=0.215$ 0.478), body ( $r=0.286-0.484)$ and limbs development $(r=0.122-0.422)$, morphological udder qualities $(r=0.264-0.461)$ and from 
the final score of type $(r=0.231-0.468)$ with a reliability of $P<0.05-0.001$. Results of estimation the daughters of the herd bull-sires by descriptive body parts of the conformation showed a significant variability by the assessed traits, which varied within 3.2-7.5 scores with variability in the coefficients of variation within 11.2-33.8\% and indicated about the need for their improvement.

Key words: Ukrainian Black-and-White dairy breed, bull-sires, linear type assessment, conformation, correlation

Дата надходження до редакції: 20.08.2021 р. 